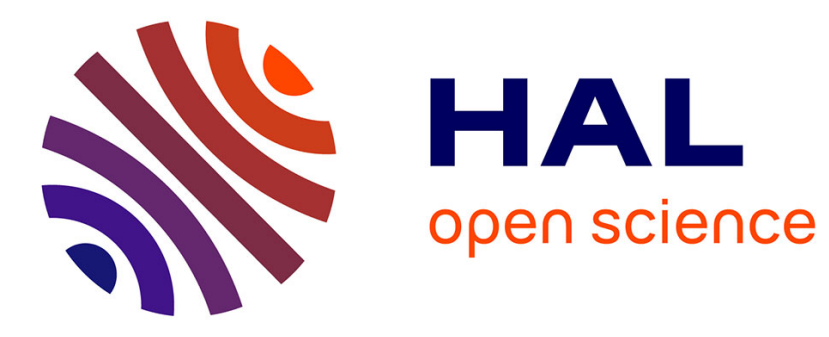

\title{
Mucins and tumor resistance to chemotherapeutic drugs
}

Nicolas Jonckheere, Nicolas Skrypek, Isabelle Van Seuningen

\section{To cite this version:}

Nicolas Jonckheere, Nicolas Skrypek, Isabelle Van Seuningen. Mucins and tumor resistance to chemotherapeutic drugs. Biochimica et Biophysica Acta (BBA) - Reviews on Cancer, 2014, 1846 (1), pp.142-151. 10.1016/j.bbcan.2014.04.008 . inserm-02341531

\section{HAL Id: inserm-02341531 https://www.hal.inserm.fr/inserm-02341531}

Submitted on 31 Oct 2019

HAL is a multi-disciplinary open access archive for the deposit and dissemination of scientific research documents, whether they are published or not. The documents may come from teaching and research institutions in France or abroad, or from public or private research centers.
L'archive ouverte pluridisciplinaire HAL, est destinée au dépôt et à la diffusion de documents scientifiques de niveau recherche, publiés ou non, émanant des établissements d'enseignement et de recherche français ou étrangers, des laboratoires publics ou privés. 


\section{Mucins and tumor resistance to chemotherapeutic drugs}

Nicolas Jonckheere ${ }^{\mathbf{1 , 2 , 3}} *$, Nicolas Skrypek ${ }^{\mathbf{1 , 2}, 3}$, , and Isabelle Van Seuningen ${ }^{1,2,3}$

1 Inserm, UMR837, Jean Pierre Aubert Research Center, Team \#5 “Mucins, Epithelial

Differentiation and Carcinogenesis”, rue Polonovski, 59045 Lille Cedex, France

2 Université Lille Nord de France, Lille, France

3 Centre Hospitalier Régional et Universitaire de Lille, Place de Verdun, 59037 Lille cedex, France.

* Authors have equally contributed to this manuscript

Corresponding author:

Dr Nicolas Jonckheere, Inserm UMR837/JPARC, rue Polonovski, 59045 Lille Cedex, France, Phone: +33 3202988 76, Fax: +33 3205385 62, E-Mail: nicolas.jonckheere@ inserm.fr 


\begin{abstract}
Epithelial cancer patients that are not considered eligible for surgical resection frequently benefit from chemotherapy. Chemotherapy is the treatment of cancer with one or combination of cytotoxic or cytostatic drugs. Recent advances in chemotherapy allowed a great number of cancer patients to receive treatment with significant results. Unfortunately, resistance to chemotherapeutic drug treatment is a major challenge for clinicians in the majority of epithelial cancers because it is responsible for the inefficiency of therapies.

Mucins belong to a heterogeneous group of large $O$-glycoproteins that can be either secreted or membrane-bound. Implications of mucins have been described in relation to cancer cell behavior and cell signaling pathways associated with epithelial tumorigenesis. Because of the frequent alteration of the pattern of mucin expression in cancers as well as their structural and functional characteristics, mucins are thought to also be involved in response to therapies. In this report, we review the roles of mucins in chemoresistance and the associated underlying molecular mechanisms (physical barrier, apoptosis resistance, drug catabolism or exclusion, cell stemness, epithelial mesenchymal transition) and discuss the therapeutic tools/strategies and/or prognosis biomarkers for personalized chemotherapy response that could be proposed from these studies.
\end{abstract}

Keywords: mucin, cancer, resistance, chemotherapeutic drug, apoptosis, prognosis biomarker 


\section{Abbreviations}

PDAC: Pancreatic ductal adenocarcinoma

CRC: Colorectal cancer

EMT: Epithelial mesenchymal transition

MUC1-CT: MUC1 cytoplasmic tail

N-t : Amino-terminal

C-t : Carboxy-terminal

PTS: Proline Threonine Serine 


\section{Introduction}

Mucins belong to an heterogeneous group of large $O$-glycoproteins composed of a long peptidic chain (called apomucin) on which are linked hundreds of oligosaccharidic chains. Initially, the mucin word designated glycoproteins secreted by specialized epithelial cells, the goblet cells, as part of the mucus gel. Mucins were biochemically characterized as massive molecules with high molecular weight able to form viscoelastic gels and responsible for the rheological properties of mucus [1]. The molecular era that led to genome sequencing allowed the classification of two sub-groups of mucins: (i) secreted mucins that mostly complied with this definition and (ii) membrane-bound or transmembrane mucins that did not fit in. Despite this dichotomy, mucins were all included in the MUC family with the approval of Human Genome Organization Gene Nomenclature Committee (HUGO/GNC) [2].

Secreted mucins are the major components of viscoelastic mucus gels and form a tridimensional network that protects the epithelia against various agression (inflammation, bacteria, virus, pollutants, $\mathrm{pH}$, etc). This subgroup mainly includes: MUC2, MUC5AC, MUC5B, MUC6 (clustered on the p15 arm of chromosome 11) and MUC19. MUC7 and MUC9 are smaller secreted mucins that do not oligomerize and are secreted by specialized cells as monomers [3-5]. Secreted mucins comprise amino (N-t) and carboxyl terminal (C-t) regions sharing structural domains with von Willebrand $(\mathrm{vW})$ factor. The central part is enriched in Pro, Thr and Ser amino acid residues forming the variable PTS domain that is Oglycosylated [4]. The $O$-glycosylation process is crucial for mucin secretion, stability, processing, and functions during both development and pathophysiological conditions [6-8]. The adjacent CYS domains are highly hydrophobic and are believed to cause the aggregation of mucins [9]. By forming disulfide bonds, the main intestinal mucin MUC2 dimerizes via its C-terminal cysteine-knot (CK) domain and also trimerizes via $\mathrm{N}$-t vWD domains building a 
complex molecular network $[10,11]$. On the contrary MUC5AC and MUC5B are linear disulfide-linked polymers that polydisperse and that behave as random coils in solution [4]

The membrane-bound mucins are type I membrane-anchored proteins including MUC1, MUC3, MUC4, MUC12, MUC13, MUC15, MUC16, MUC17, MUC20, MUC21 and MUC22 [12-14]. Typically, membrane-bound mucins contain a long extracellular domain, a hydrophobic transmembrane domain, and a short cytoplasmic tail. Analysis of the peptidic sequences of mucins allowed description of their modular organization. The PTS domain, the only domain not conserved at the genomic level, is the common feature between mucins. Membrane-bound mucins share conserved domains such as epidermal growth factor-like (EGF) or Sea urchin sperm protein Enterokinase and Agrin (SEA) domains [13, 15, 16]. Based on their structure and localization at the cell surface they were shown to act in cell-cell, cell-extracellular matrix interactions and in cell signaling.

Mucins have a cell- and tissue-specific patterns of expression profoundly altered in epithelial cancers (loss of expression, over-expression, aberrant expression, neo-expression, glycosylation alterations) [17-21]. Because of their specific pattern of expression during the different steps of tumor progression toward adenocarcinoma, mucins stay under intense investigation as both potent new biomarkers and therapeutic targets in epithelial cancers.

Numerous reviews in the literature describe the roles of mucins in relation to cancer cell behavior and cell signaling pathways associated with tumorigenesis. Among them, membrane-bound mucins MUC1 and MUC4 have been extensively studied [14, 22-25]. MUC1 and MUC4 govern both cellular differentiation and proliferation. They are also involved in metastasis and tumor proliferation. Secreted mucins MUC5B and MUC5AC and membrane bound mucins MUC13 and MUC16 have also been associated with aggressive behavior of cancer cells [26-31]. On the contrary, Muc2 is involved in the suppression of 
colorectal cancer (CRC) since Muc $2^{\mathrm{KO}}$ mice develop adenoma progress with age to invasive adenocarcinoma in the small intestine [32].

The dramatic outcome of epithelial cancers of the gastrointestinal tract is often related to a lack of efficient therapeutic tools and early diagnostic markers. Patients that are not considered eligible for surgical resection frequently benefit from chemotherapy. However, chemoresistance is a common feature of epithelial cancers. Lately, mucins have been proposed as actors of this phenomenon. In this review, we will discuss their role and the associated cellular mechanisms in chemoresistance in order to propose them as therapeutic tools and/or prognosis biomarkers of chemotherapy response.

\section{Mucins and chemoresistance in vitro}

In our laboratory and others, initial in vitro studies showing the relationship between mucin and chemoresistance came from colorectal carcinoma cells (HT29) stably resistant to 5fluorouracil or methotrexate [33-35]. These cells were characterized by the overexpression of secreted mucins when they became resistant cells. This observation pointed out to the potential of mucins as actors of chemoresistance (Table I).

In breast cancer cells, the overexpression of MUC1 is involved in cell sensitivity to Herceptin ${ }^{\circledR}$ via the increase of the cleavage of this mucin. These cells are also resistant to paclitaxel (Taxol®), doxorubicin and cyclophosphamide, suggesting a broader involvement of membrane-bound mucins [36]. Similarly, silencing the MUC1 or MUC4 gene can reverse resistance to trastuzumab in HER2-positive gastric cancers [37, 38].

Xenograft tumors of estrogen receptor positive (ER)/HER2-overexpressing breast cancer cells, that are developing resistance to lapatinib and trastuzumab, harbor an increase in mucinfilled vacuoles and upregulation of several mucins including MUC4 [39] suggesting a role of MUC4 in acquired resistance to chemotherapy. MUC4 influence on chemosensitivity has 
been studied in pancreatic cancer cells using gain or loss of function strategies. Several reports showed that MUC4 protects pancreatic cancer cells from gemcitabine-induced cytotoxicity [40-43]. Similar observation was made regarding another cytidine analog, the cytarabine/aracytin ARA-C [42] or 5-fluoro-uracile (unpublished data). Overexpression of rat orthologue MUC4/SMC in melanoma cells also reverts antiproliferative effect of taxol, doxorubicin, vinblastine, rhodamine-123 or 2-deoxyglucose and cell death induced by doxorubicin [44]. Finally MUC4 expression was also shown to reduce the mitochondrial damage in pancreatic cancer cells induced by the inhibition of the proteasome when treated by the boronic acid derivative bortezomib [43].

\section{Mucins and clinical response to chemotherapy}

\subsection{Mucinous tumors}

Retrospective clinical studies indicate that mucinous carcinoma or adenocarcinoma (uterine, colorectal or breast cancer), characterized by an abundant mucus gel covering the tumor, are less sensitive to neoadjuvant chemotherapies and radiotherapies. These data support that a link exist between the mucus and chemotherapeutic efficiency in the tumor context [45-48]. In advanced gastric cancer, the signet ring cell (SRC) histologic subtype, characterized by cells containing a large mucus vacuole, is an independent predictor of poor prognosis. Moreover, perioperative chemotherapy provides no benefit on survival [49]. However, the direct involvements of secreted mucins in these clinical observations, as well as the associated underlying cellular mechanisms, remain to be determined.

\subsection{Non-mucinous tumors}

On the contrary, a fair number of studies have shown that tumors expressing MUC1 exhibit an increased capacity to resist the effects of chemotherapeutic drugs in breast and ovarian 
cancers. Frequency analysis of MUC1 expression in an important cohort of 691 breast cancer biopsies showed that both MUC1 mRNA and protein high expression was associated with lower probability of complete response to neoadjuvant chemotherapy [50]. MUC1 regulates cholesterol and fatty acid metabolism in human breast cancer. Activation of these pathways in $\mathrm{ER}(+)$ breast cancers predicts failure to tamoxifen treatment with higher risk for death and recurrence/distant metastasis [51].

MUC1 protein level is significantly increased in platinum resistant ovarian tumors compared to those in sensitive-group because of chromosomal amplifications of 1q21-q22 [52]. A follow-up analysis of 92 ovarian cancer patient cohort also showed that the increase of MUC1 expression is a significant risk factor for chemoresistance to taxane combined platinum-based drugs in patients with ovarian epithelial cancer [53].

\section{Mucins form a physical barrier}

The outstanding web formed by the secreted mucus as well as the extraordinary size of heavily glycosylated membrane-bound mucins such as MUC1, MUC4 or MUC16 (>10 6 Da) suggest that mucins are capable to limit (i) drug intracellular entrance and/or (ii) the accessibility of the plasma membrane and its tumor cell epitopes for immune recognition or antibody-based therapy (Figure 1A).

Because of the viscosity/rheology of the mucus, secreted mucins may stop poorly soluble drugs diffusion through the cell membrane. In diseases characterized by dense mucus such as chronic inflammatory cystic fibrosis, the mucus permeability is also decreased making the diffusion more difficult for therapeutics molecules [54]. Two functions are hypothesized: Either mucins act as size filters and allow the entrance of drugs smaller than mucus network holes, or they act as interaction filters via electrostatic or hydrophobic forces accordingly to their surface properties and independently of drug molecular size [55] as ionisation of the 
drug was shown to influence its diffusion through mucus [56]. The size, the electric charge and the hydrophilic property of mucins molecules composing the mucus is critical for the permeability. The electronegative potential of mucins, mostly carried by sialic acids on $O$ glycosidic chains, could affect the interaction affinity of mucus [20] and can create electrostatic interactions with positively charged molecules (as amikacin or gemcitabine) decreasing their diffusion [57].

The steric hindrance of membrane-bound mucins is closely linked to the number and length of O-glycosidic chains worn by mucins. The benzyl-2-acetamido-2-deoxy- $\alpha$-dgalactopyranoside (benzyl- $\alpha-$ GalNAc) is a reagent used to inhibit the synthesis of mucin Oglycosylation in cellular models. The inhibition of $O$-glycosylation in MUC1 expressing CAPAN-1 and HPAF-II pancreatic tumor cells resulted in significant 5-fluorouracile (5-FU) antiproliferative activity [58]. Benzyl- $\alpha$-GalNAc that leads to a storage phenotype and abnormal intracellular localization of apical glycoproteins, does not alter directly mucin expression in CAPAN-1 cells since it was previously shown that MUC1 kept its normal localization [59]. Therefore, Kalra and Campbell speculated that the inhibition of mucin glycosylation may reduce the formidable mucin O-glycosylation mesh and facilitate the entrance of chemotherapeutic drug [58]. In this model, the mucin network is thought to limit the intracellular uptake of 5-FU and to attenuate its chemotherapeutic effect independently of sialic acid [60]. The mucus layer on the surface of normal epithelial cells was also shown to limit the diffusion of nutrients and small molecules depending on their size and physicochemical properties [61].

The overexpression of the high-molecular weight glycoprotein membrane-bound mucins on the target tumor cell surface can mask the surface antigens, and thereby decrease their accessibility and the cytotoxic response induced by antibody-based therapy as well as the tumor cell killing mediated by immune cells. It has been shown that overexpression of rMuc4, 
MUC1 or MUC16 can create an immunosuppressive barrier by decreasing the accessibility of immune cells (as lymphokine-activated killer cell) to antigenic epitope dependent on $O$ glycosylation length [62-64]. The overexpression membrane-bound mucins block drug accessibility to therapeutic targets such as oncogenic receptors EGFR, ErbB2, VEGFR targeted by Erbitux/Cetuximab, Herceptin/trastuzumab, Avastin/Bevacizumab, respectively. The overexpression of rMuc4 in pancreatic cancer cell has been shown to decrease the recognition and thus the efficiency of the monoclonal antibody trastuzumab (Herceptin) which targets the oncogenic receptor ErbB2 [65]. A converse correlation has been established between the expression of MUC4 and Herceptin sensitivity in mammary cancer cells. The JIMT-1 cell line expressing the highest level of MUC4 is highly resistant to this monoclonal antibody [66].

\section{Resistance to apoptosis}

The induction of apoptosis is the main goal of all cytotoxic therapy. Programmed cell death resistance is a major cause of chemoresistance in which expression of mucins can reduce the sensitivity of cancer cells to genotoxic drugs by decreasing the apoptotic effect following DNA damages or physiologic stress (Figure 1B).

\subsection{MUC1}

MUC1 role as an apoptotic inhibitor in cancer cells is well-documented (Figure 2). Indeed, MUC1 decreases apoptotic mitochondrial factors release, caspase-3 activation, and subsequent apoptosis induction in CRC cells treated with the genotoxic agent cisplatine [67]. MUC1 cytoplasmic tail (MUC1-CT) inhibits the activation of a large array of intrinsic apoptotic pathways by regulating different signaling pathways such as p53, FOXO3a, c-Abl, IкB complex, FADD or Bax. MUC1-CT interacts with p53 tumor suppressor on its 
responsive elements to coactivate p21 at the transcriptional level. On the contrary, MUC1 attenuates Bax transcription [68]. MUC1-CT also associates with Bax in the cytoplasm and the mitochondria via their $\mathrm{CQC}$ motif and $\mathrm{BH} 3$ domains, respectively, and blocks Bax dimerisation and subsequent cytochrome c release that normally activate the mitochondrial death pathway [69]. MUC1-CT anti-apoptotic function is also mediated via c-Abl sequestration within the cytoplasm and blocking of c-Abl and cytosolic 14-3-3 interaction [70]. Mutation of MUC1-CT at Tyr 60 (Y60F) disrupts the MUC1-Abl interaction inducing ARF expression and inhibiting MDM2-p53 pathway [71]. MUC1 is important for

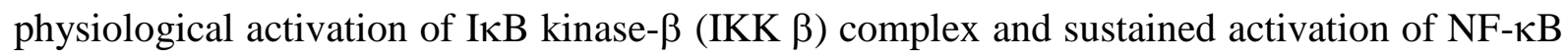
pathway in response to TNF- $\alpha$ activation [72]. In response to TNF- $\alpha$, MUC1-CT also interacts with caspase-8 and Fas-associated death domain following death receptor stimulation and block the activation of apoptosis process [73]. In clear renal cell carcinoma (cRCC), overexpression of MUC1 prevents anoïkis through anti-apoptotic NF- $\kappa \mathrm{B}$ nuclear localization, caspase- 9 expression and the increase of $\mathrm{Bcl}_{\mathrm{XL}} / \mathrm{Bax}$ ratio [74].

Normal cellular metabolism is associated with the production of reactive oxygen species (ROS) including superoxide ion $\left(\mathrm{O}_{2}{ }^{-}\right)$, hydrogen peroxide $\left(\mathrm{H}_{2} \mathrm{O}_{2}\right)$, hydroxyl radicals, and nitric oxide. Increase in ROS levels can cause damage to DNA, proteins, and lipids [75, 76]. MUC1 reduces apoptosis following oxidative stress by regulating endogenous and $\mathrm{H}_{2} \mathrm{O}_{2^{-}}$ induced intracellular levels of ROS. Reciprocally, MUC1 expression is up-regulated by oxidative stress at the transcriptional level [77]. MUC1-CT also induces FOXO3a activation and attenuates the oxidative stress in colon and breast cancer cells [78]. Chronic ROS exposure leads to HIF-1 $\alpha$ stabilization and up-regulation of downstream target genes [79]. Among them, MUC1 is directly regulated by HIF-1 $\alpha$ in kidney cancer cells [80].

\subsection{MUC4}


An anti-apoptotic role has been described for MUC4 in serum-free conditions $[81,82]$ as well as following drug treatment with thymoquinone, an antioxidant and anti-tumoral compound found in plants [83], or with gemcitabine [40, 42]. MUC4 expression induces apoptosis via multiple intracellular mechanisms (Figure 3). It reduces mitochondrial cytochrome c release and activation of caspase-9 through phosphorylation of its partner HER2 and sequestration of pro-apoptotic Bad in the cytosol $[40,41]$. Loss of MUC4 oncoprotein is accompanied by a blockage in the G1-early $\mathrm{S}$ phases [41, 84], an increased expression of the proapoptotic marker Bax and apoptotic mediator p53 as well as a decreased expression of the antiapoptotic $\mathrm{Bcl}_{\mathrm{XL}}$ suggesting a higher susceptibility to apoptosis [42]. The overexpression of rMuc4 induces chemoresistance to paclitaxel, doxorubicin and cisplatin. In this case, rMuc4 expression decreases PARP and caspase-9 cleavage and modulates apoptosis $[44,85]$. rMuc4 may also repress apoptosis via an ErbB2-dependent mechanism, in which rMuc4 potentiates the activation of ErbB2 by phosphorylation of the Y1248 leading to activation of the PI3K/Akt pathway, and via an ErbB2-independent mechanism that remains to be determined $[86,87]$. MUC4 overexpression in ovarian cancer cells also leads to increased CD133 ${ }^{+}$cell population. CD133 is a pentaspan transmembrane glycoprotein associated with chemoresistance, radio-resistance and poor prognosis and is commonly used as stem cell marker (see §7). Additionally, $\mathrm{CD} 133^{+}$cell population demonstrates significant resistance to drug-, TGF$\beta$ - and TNF-related apoptosis-inducing ligand (TRAIL)- induced apoptosis compared with CD133- cells $[88,89]$ suggesting that CD133 triggers resistance to apoptosis in MUC4expressing cells via similar mechanisms.

\section{Mucins and alteration of drug metabolism}

In pancreatic cancer, chemoresistance has been attributed partly to the enhanced expression of multidrug resistance (MDR) genes (Figure 1C) including ATP-binding cassette transporter 
genes (ABCC)1, ABCC3, ABCC5 and ABCB1 that encode MDR related proteins (MRP)-1, MRP3, MRP5 and MDR1 proteins, respectively [90]. The proteins encoded by this gene family are ATP-dependent drug efflux pumps for xenobiotic compounds with broad substrate specificity [91]. Notably, cleaved MUC1-CT directly associates and activates the ABCC1 promoter and increases (i) ABCC1 protein level in MUC1-high pancreatic cancer cells and (ii) resistance to gemcitabine and etoposide chemotherapeutic drugs [90] (Figure 2).

One way to explain modifications of cell sensitivity to nucleoside analog such as gemcitabine or 5-FU is an alteration of the actors responsible for their metabolism and more particularly nucleoside transporters. We and others have described a major role for MUC4 in resistance to gemcitabine chemotherapy [40-42] involving alteration of nucleotide metabolism. In that case, MUC4 mucin negatively regulates the hCNT1 transporter expression via the NF-kB pathway, pointing out to MUC4 and hCNT1 as potential new targets to ameliorate the response of pancreatic tumors to gemcitabine treatment [42].

\section{Cancer stem cells}

The ability to relapse after therapy is frequently dependent on a small subset of the cell population within the tumor, called cancer stem cells (CSC) or side population (SP) (Figure 1D), characterized by an extensive self-renewing capacity [92]. Some therapies including chemotherapy may provide strong selection for CSC survival and proliferation [93].

Very recently, MUC1-CT was shown to upregulate expression of breast CSC marker Aldehyde dehydrogenase 1A1 (ALDH1A1) via Erk1 and C/EBP $\beta$ by forming a transcriptional activating complex on the ALDH1A1 gene promoter [94]. MUC1 was also shown to be expressed by $\mathrm{CD} 34^{+} \mathrm{CD} 38^{-}$acute myeloid leukemia (AML) cells which have been associated with leukemia stem cells (LSC) suggesting that MUC1 represents a potential target on the AML stem cell population [95]. 
In ovarian cancer, MUC4 overexpression leads to increased CD133-positive CSC [96] (Figure 3). Stem cell-like marker CD133 is also observed in a small subpopulation of pancreatic epithelial cells in the basal compartment in non-malignant pancreatic tissue specimens. This subpopulation also expresses MUC4 membrane-bound mucin [41]. MUC4 oncoprotein which is normally not expressed in the normal pancreas, is expressed at a high level in both the small

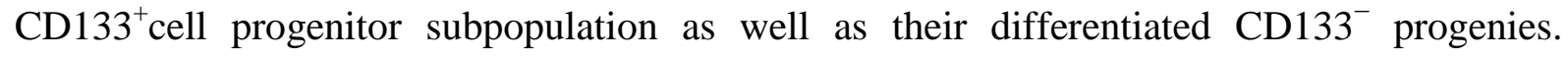
Mimeault et al have suggested that MUC4 down-regulation can partially reverse the resistance of CD133+ initiating cells to the gemcitabine treatment [41]. This is notably important since gemcitabine treatment of pancreatic tumor xenografts leads to enrichment of cell subpopulations expressing stem cell markers such as ALDH and CD24 as well as efflux pumps such as $\mathrm{ABCB} 1$ and $\mathrm{ABCG} 2$ [97, 98]. MUC4 oncoprotein may thus represent a promising therapeutic strategy in that matter.

\section{Epithelial-mesenchymal transition (EMT)}

EMT is a physiological and pathological reversible biological process associated with loss of cellular polarity, decreased surface expression of epithelial markers (E-cadherin, cytokeratin18, ZO-1) and increase mesenchymal markers expression (vimentin, N-cadherin, MMP-9, ZEB-1) (Figure 1E) [99, 100]. EMT inducers include notably transcription factors, such as Snail, Slug, twist1/2, transforming growth factor (TGFß) pathway or miRNA [101, 102]. Many reports show that EMT is a major step toward metastatic tumor progression and contributes to drug resistance and acquisition or selection of stem/progenitor-like features and ultimately recurrence [103-106].

MUC1 MUC4 and MUC16 are able to trigger the molecular process of EMT [107-110]. The mucin-induced EMT implies interaction with $\beta$-catenin that leads to cell-cell junction disruption and invasiveness. Interestingly, MUC1-CT interacts with $\beta$-catenin and 
translocates to the nucleus in order to upregulate EMT initiating genes. Moreover, MUC1-CT occupies and induces the $Z E B 1$ promoter by a NF- $\mathrm{B}$ p 65 -dependent mechanism. In turn ZEB1 associates with MUC1-CT and contributes to suppress miR200c expression that promotes EMT [111]. In cRCC, MUC1-CT also occupies the Snail promoter, modulates the binding of $\beta$-catenin and trigger EMT [112]. The cellular mechanisms underlying EMT related to MUC4 or MUC16 are not fully understood but might involve signaling pathway deregulation.

The relation between MUC4 and EMT is controversial since MUC4 was shown to suppress EMT in lung adenocarcinoma $[113,114]$ whereas MUC4 overexpression in ovarian cancer led to decreased expression of epithelial markers and occurrence of mesenchymal markers via an upregulation of Twist1, Twist2 and Snail transcription factors and FAK signaling pathway [110]. Collectively, these results suggest that MUC4 may regulate EMT in both ways depending on the cellular context. Complementary studies need to be carried out in order to elucidate these discrepancies regarding MUC4.

One may hypothesize that targeting EMT using MUC1 or MUC16 mucin as a therapeutic approach may be effective since mucins are involved in both chemoresistance and EMT that often lead to tumor recurrence. Recently, MUC1 siRNA was shown to inhibit both cell proliferation and EMT in urinary bladder cancer [115].

\section{Mucins and polymorphisms associated with chemosensitivity?}

As genomic sequencing cost declines rapidly, the availability of pangenomic information promotes the era of pharmacogenomics and therefore personalized medicine. The genetic diversity between different population and ethnic backgrounds might explain a high degree of variability of drug response and adverse drug reactions [116]. Frequency differences of 
polymorphisms exist across different geographic regions for drug transporters or genes involved in drug metabolisms [117, 118].

Mucin single nucleotide polymorphisms (SNP), associated with various diseases including cancer, have been described $[119,120]$. Moreover, the SNP distributions differ between subjects from different origins (Caucasian or Asian) [121]. Mucin genes also exhibit a high degree of polymorphisms in the VNTR domain [122]. The variation of VNTR length leads to quantitative differences of the O-glycan content and alters biophysical properties of the glycoprotein. Among MUC associated with disease, gastric cancer patients harbor a higher proportion of short MUC1 allele compared to a control population [123]. Despite these data, no direct association between mucin polymorphism (SNP or VNTR) and sensitivity to chemotherapeutic drugs has been described so far.

\section{Outlook to the future: Using mucins as a therapeutic target to sensitize cancer cells to chemotherapeutic drugs or as biomarkers of chemoresistance?}

Since oncomucin expression in cancer cells is linked to a higher susceptibility to apoptosis, an increased expression of multidrug resistance markers, and stem cell characteristics, this could represent a valuable therapeutic strategy to decrease tumor resistance. Because of their high molecular weight and their high sugar content, extraction and purification of native mucins for therapy is notoriously difficult [124]. Therefore, native mucins were never used concomitantly with chemotherapeutic drugs. However, mucins expression or functionality was targeted in order to sensitize cancer cells to chemotherapeutic drugs.

Peptide inhibitors targeting MUC1-CT were shown to block its interaction with NF- $\kappa \mathrm{B}$ and to activate the induction of late apoptosis/necrosis in myeloma cells [125]. 
Silencing of MUC1 C-terminal subunit in HER2-overexpressing breast cancer cells or treatment with the penetrating peptide inhibitor, G0-203, reverses chemoresistance to trastuzumab, tamoxifen, taxol and doxorubicin (Figure 2) [126-128].

Silencing MUC1-CT is associated with (i) downregulation of HER2 phosphorylation and (ii) sensitivity to tamoxifen-induced growth inhibition and loss of clonogenic survival. HER2positive cancer cells that are intrinsically resistant to trastuzumab became sensitive when treated with an antagonist of the cleaved form of the MUC1 protein [36]. In bladder cancer, MUC1 silencing also leads to reduction of tumor volume in vivo and suppresses EMT. However, the impact on chemosensitivity remains to be proven in this case [115].

Currently, phase 1 multi-center clinical trial testing G0-203 dose-escalation, safety, pharmacodynamic and pharmacokinetic in solid tumors and lymphomas is in progress (ClinicalTrials.gov identifier: NCT01279603). G0-203 also resulted in tumor regression independently of chemotherapy, in non-small cell lung cancer cells and acute myeloid leukemia [95, 129].

Numerous studies are already targeting MUC1 as an immunotherapeutic approach [130-133]. Mucins could also be used in modified vectors sensitizing the tumor to targeted chemotherapy. In OVCAR-3 ovarian cancer cells, a MUC1/let-7i chimera, combines MUC1 aptamer and let-7i miRNA, can specifically reverse chemoresistance to paclitaxel [134]. Similarly a MUC1/miR-29b chimera also reverses chemoresistance to paclitaxel [135]. However, these effects on chemoresistance are independent of MUC1 structure since the MUC1 aptamer alone does not influence the induced apoptosis.

Therapy-predictive markers are factors that prospectively identify response or resistance to a specific treatment. They allow distinguishing patients with the same histological type of malignancy that respond very differently to a specific drug [136]. In CRC, the presence of acellular mucin pools in the resected specimens of patients with a complete response to 
preoperative chemoradiation is frequently reported as a marker of treatment effect. However, several reports ruled out its prognostic significance [137-139].

An ideal marker implicates non-invasive and rapid procedures of detection. Therefore, clinicians routinely use robust circulating markers in the blood or markers such as tumorassociated antigens. MUC1 (CA15-3) and MUC16 (CA125) tumor-associated antigens are commonly detected in patients' sera by standardized tests such as ELISA or immunohistochemistry [136, 140]. MUC1 and MUC16 are overexpressed in ovarian cancer [17, 141]. Budiu et al., showed that increased serum MUC1 level has a prognostic value for poor clinical response and reduced overall survival in platinum-resistant or platinumrefractory ovarian cancer whereas MUC16 was not associated with clinical response [140]. In a multivariable analysis, MUC1 protein and mRNA expression were independently predictive in a breast cancer cohort [50]. CA15.3 level is also correlated with treatment response in patients undergoing chemotherapy for metastatic breast cancer [142]. Detection of (MUC1)-positive circulating tumor cells and MUC1 protein in the peripheral blood of patients with metastatic breast cancer is thus associated with higher progression-free survival (PFS) [143]. 


\section{Conclusion}

Over the past two decades, spectacular advances in targeted therapy led to improvement of treatment of a great numbers of cancer patients. These outstanding results are counterbalanced by the increased occurrence of acquired or intrinsic events of chemoresistance that limits long term success. Many evidence support the involvement of both membrane-bound and secreted mucins in diverse biological mechanims of resistance (physical barrier, apoptosis resistance, drug catabolism or exclusion, cell stemness, EMT). Understanding mechanisms of resistance involving mucins shall contribute to the development of next generation targeted therapy molecules. Alternatively, mucins will help in the prevention because of their potential as tumor biomarkers and orientate the therapeutic choice tree toward the potentially more successful therapy and more importantly avoid a more aggressive alternate therapy that is promised to failure. 


\section{Acknowledgements}

We are grateful to Dr M. Perrais and Dr A. Vincent (Inserm UMR837, Lille) for their critical reading of the manuscript. This research was supported by SIRIC ONCOLille, Grant INCaDGOS-Inserm 6041 and by a grant from la Ligue Nationale Contre le Cancer (Equipe Labellisée Ligue 2010, IVS). Isabelle Van Seuningen is the recipient of a "Contrat Hospitalier de Recherche Translationnelle"/CHRT 2010, AVIESAN. 


\section{References}

[1] P. Roussel, G. Lamblin, M. Lhermitte, N. Houdret, J.J. Lafitte, J.M. Perini, A. Klein, A. Scharfman, The complexity of mucins, Biochimie, 70 (1988) 1471-1482.

[2] J. Dekker, J.W. Rossen, H.A. Buller, A.W. Einerhand, The MUC family: an obituary, Trends Biochem Sci, 27 (2002) 126-131.

[3] S.J. Gendler, A.P. Spicer, Epithelial mucin genes, Annu Rev Physiol, 57 (1995) 607-634.

[4] D.J. Thornton, K. Rousseau, M.A. McGuckin, Structure and function of the polymeric mucins in airways mucus, Annu Rev Physiol, 70 (2008) 459-486.

[5] J.L. Desseyn, V. Gouyer, D. Tetaert, Architecture of the gel-forming mucins, in: I. Van Seuningen (Ed.) The Epithelial Mucins: Structure/Function. Roles in Cancer and Inflammatory Diseases, Research Signpost, Kerala, India, 2008, pp. 1-16.

[6] S.E. Baldus, K. Engelmann, F.G. Hanisch, MUC1 and the MUCs: a family of human mucins with impact in cancer biology, Crit Rev Clin Lab Sci, 41 (2004) 189-231.

[7] D.T. Tran, K.G. Ten Hagen, Mucin-type O-glycosylation during development, J Biol Chem, 288 (2013) 6921-6929.

[8] S. Groux-Degroote, A. Harduin-Lepers, P. Delannoy, Biosynthesis of mucin O-glycan chains in normal and pathological states, in: I. Van Seuningen (Ed.) The Epithelial Mucins: Structure/Function. Roles in Cancer and Inflammatory Diseases, Research Signpost, Kerala, India, 2008, pp. 39-54.

[9] J.L. Desseyn, Mucin CYS domains are ancient and highly conserved modules that evolved in concert, Mol Phylogenet Evol, 52 (2009) 284-292.

[10] D. Ambort, M.E. Johansson, J.K. Gustafsson, A. Ermund, G.C. Hansson, Perspectives on mucus properties and formation--lessons from the biochemical world, Cold Spring Harb Perspect Med, 2 (2012) pii: a014159.

[11] M. Backstrom, D. Ambort, E. Thomsson, M.E. Johansson, G.C. Hansson, Increased understanding of the biochemistry and biosynthesis of MUC2 and other gel-forming mucins through the recombinant expression of their protein domains, Mol Biotechnol, 54 (2013) 250-256.

[12] C.L. Hattrup, S.J. Gendler, Structure and function of the cell surface (tethered) mucins, Annu Rev Physiol, 70 (2008) 431-457.

[13] N. Jonckheere, N. Skrypek, F. Frenois, I. Van Seuningen, Membrane-bound mucin modular domains: from structure to function, Biochimie, 95 (2013) 1077-1086.

[14] N. Jonckheere, I. Van Seuningen, The membrane-bound mucins: how large O-glycoproteins play key roles in epithelial cancers and hold promise as biological tools for gene-based and immunotherapies, Crit Rev Oncog, 14 (2008) 177-196.

[15] J.L. Desseyn, D. Tetaert, V. Gouyer, Architecture of the large membrane-bound mucins, Gene, 410 (2008) 215-222.

[16] B.H. Perez, I.K. Gipson, Focus on Molecules: human mucin MUC16, Exp Eye Res, 87 (2008) 400-401.

[17] N. Jonckheere, I. Van Seuningen, The membrane-bound mucins: From cell signalling to transcriptional regulation and expression in epithelial cancers, Biochimie, 92 (2010) 1-11.

[18] I. Van Seuningen, P. Pigny, M. Perrais, N. Porchet, J.P. Aubert, Transcriptional regulation of the 11 15 mucin genes. Towards new biological tools in human therapy, in inflammatory diseases and cancer?, Front Biosci, 6 (2001) D1216-1234.

[19] R. Pinto, A.S. Carvalho, T. Conze, A. Magalhaes, G. Picco, J.M. Burchell, J. Taylor-Papadimitriou, C.A. Reis, R. Almeida, U. Mandel, H. Clausen, O. Soderberg, L. David, Identification of new cancer biomarkers based on aberrant mucin glycoforms by in situ proximity ligation, J Cell Mol Med, 16 (2012) 1474-1484.

[20] C. Robbe-Masselot, J.C. Michalski, C. Capon, Tumour-associated antigens of mucin O-glycans. Clinical relevance of glycobiology in cancer and inflammatory diseases of the epithelium, in: I. Van Seuningen (Ed.) The Epithelial Mucins: Structure/Function. Roles in Cancer and Inflammatory Diseases, Research Signpost, Kerala, India, 2008, pp. 55-74.

[21] P. Argueso, I.K. Gipson, Assessing mucin expression and function in human ocular surface epithelia in vivo and in vitro, Methods Mol Biol, 842 (2012) 313-325.

[22] M.A. Hollingsworth, B.J. Swanson, Mucins in cancer: protection and control of the cell surface, Nat Rev Cancer, 4 (2004) 45-60.

[23] N. Jonckheere, N. Skrypek, I. van Seuningen, Mucins and pancreatic cancer, Cancers, 2 (2010) 1794-1812. 
[24] S. Kaur, S. Kumar, N. Momi, A.R. Sasson, S.K. Batra, Mucins in pancreatic cancer and its microenvironment, Nat Rev Gastroenterol Hepatol, 10 (2013) 607-620.

[25] D.W. Kufe, Mucins in cancer: function, prognosis and therapy, Nat Rev Cancer, 9 (2009) 874-885. [26] H. Hoshi, T. Sawada, M. Uchida, H. Saito, H. lijima, M. Toda-Agetsuma, T. Wada, S. Yamazoe, H. Tanaka, K. Kimura, A. Kakehashi, M. Wei, K. Hirakawa, H. Wanibuchi, Tumor-associated MUC5AC stimulates in vivo tumorigenicity of human pancreatic cancer, Int J Oncol, 38 (2011) 619-627.

[27] H. Valque, V. Gouyer, F. Gottrand, J.L. Desseyn, MUC5B leads to aggressive behavior of breast cancer MCF7 cells, PLoS One, 7 (2012) e46699.

[28] S. Yamazoe, H. Tanaka, T. Sawada, R. Amano, N. Yamada, M. Ohira, K. Hirakawa, RNA interference suppression of mucin 5AC (MUC5AC) reduces the adhesive and invasive capacity of human pancreatic cancer cells, J Exp Clin Cancer Res, 29 (2010) 53.

[29] S.C. Chauhan, M.C. Ebeling, D.M. Maher, M.D. Koch, A. Watanabe, H. Aburatani, Y. Lio, M. Jaggi, MUC13 mucin augments pancreatic tumorigenesis, Mol Cancer Ther, 11 (2012) 24-33.

[30] D.M. Maher, B.K. Gupta, S. Nagata, M. Jaggi, S.C. Chauhan, Mucin 13: structure, function, and potential roles in cancer pathogenesis, Mol Cancer Res, 9 (2011) 531-537.

[31] I. Lakshmanan, M.P. Ponnusamy, S. Das, S. Chakraborty, D. Haridas, P. Mukhopadhyay, S.M. Lele, S.K. Batra, MUC16 induced rapid G2/M transition via interactions with JAK2 for increased proliferation and anti-apoptosis in breast cancer cells, Oncogene, 31 (2012) 805-817.

[32] A. Velcich, W. Yang, J. Heyer, A. Fragale, C. Nicholas, S. Viani, R. Kucherlapati, M. Lipkin, K. Yang, L. Augenlicht, Colorectal cancer in mice genetically deficient in the mucin Muc2, Science, 295 (2002) 1726-1729.

[33] R. Dahiya, T. Lesuffleur, K.S. Kwak, J.C. Byrd, A. Barbat, A. Zweibaum, Y.S. Kim, Expression and characterization of mucins associated with the resistance to methotrexate of human colonic adenocarcinoma cell line HT29, Cancer Res, 52 (1992) 4655-4662.

[34] T. Lesuffleur, N. Porchet, J.P. Aubert, D. Swallow, J.R. Gum, Y.S. Kim, F.X. Real, A. Zweibaum, Differential expression of the human mucin genes MUC1 to MUC5 in relation to growth and differentiation of different mucus-secreting HT-29 cell subpopulations, J Cell Sci, 106 ( Pt 3) (1993) 771-783.

[35] E. Leteurtre, V. Gouyer, K. Rousseau, O. Moreau, A. Barbat, D. Swallow, G. Huet, T. Lesuffleur, Differential mucin expression in colon carcinoma HT-29 clones with variable resistance to 5fluorouracil and methotrexate, Biol Cell, 96 (2004) 145-151.

[36] S.P. Fessler, M.T. Wotkowicz, S.K. Mahanta, C. Bamdad, MUC1* is a determinant of trastuzumab (Herceptin) resistance in breast cancer cells, Breast Cancer Res Treat, 118 (2009) 113-124.

[37] M. Deng, D.D. Jing, X.J. Meng, Effect of MUC1 siRNA on drug resistance of gastric cancer cells to trastuzumab, Asian Pac J Cancer Prev, 14 (2013) 127-131.

[38] M. Shi, Z. Yang, M. Hu, D. Liu, Y. Hu, L. Qian, W. Zhang, H. Chen, L. Guo, M. Yu, L. Song, Y. Ma, N. Guo, Catecholamine-Induced beta2-adrenergic receptor activation mediates desensitization of gastric cancer cells to trastuzumab by upregulating MUC4 expression, J Immunol, 190 (2013) 56005608.

[39] A.C. Chen, I. Migliaccio, M. Rimawi, S. Lopez-Tarruella, C.J. Creighton, S. Massarweh, C. Huang, Y.C. Wang, S.K. Batra, M.C. Gutierrez, C.K. Osborne, R. Schiff, Upregulation of mucin4 in ERpositive/HER2-overexpressing breast cancer xenografts with acquired resistance to endocrine and HER2-targeted therapies, Breast Cancer Res Treat, 134 (2012) 583-593.

[40] S. Bafna, S. Kaur, N. Momi, S.K. Batra, Pancreatic cancer cells resistance to gemcitabine: the role of MUC4 mucin, Br J Cancer, 101 (2009) 1155-1161.

[41] M. Mimeault, S.L. Johansson, S. Senapati, N. Momi, S. Chakraborty, S.K. Batra, MUC4 downregulation reverses chemoresistance of pancreatic cancer stem/progenitor cells and their progenies, Cancer Lett, 295 (2010) 69-84.

[42] N. Skrypek, B. Duchene, M. Hebbar, E. Leteurtre, I. van Seuningen, N. Jonckheere, The MUC4 mucin mediates gemcitabine resistance of human pancreatic cancer cells via the Concentrative Nucleoside Transporter family, Oncogene, 32 (2013) 1714-1723.

[43] T.T. Wissniowski, S. Meister, E.G. Hahn, J.R. Kalden, R. Voll, M. Ocker, Mucin production determines sensitivity to bortezomib and gemcitabine in pancreatic cancer cells, Int J Oncol, 40 (2012) $1581-1589$.

[44] Y.P. Hu, B. Haq, K.L. Carraway, N. Savaraj, T.J. Lampidis, Multidrug resistance correlates with overexpression of Muc4 but inversely with P-glycoprotein and multidrug resistance related protein in transfected human melanoma cells, Biochem Pharmacol, 65 (2003) 1419-1425.

[45] L.J. Mekenkamp, K.J. Heesterbeek, M. Koopman, J. Tol, S. Teerenstra, S. Venderbosch, C.J. Punt, I.D. Nagtegaal, Mucinous adenocarcinomas: poor prognosis in metastatic colorectal cancer, Eur J Cancer, 48 (2012) 501-509. 
[46] T. Nagao, T. Kinoshita, T. Hojo, H. Tsuda, K. Tamura, Y. Fujiwara, The differences in the histological types of breast cancer and the response to neoadjuvant chemotherapy: the relationship between the outcome and the clinicopathological characteristics, Breast, 21 (2012) 289-295.

[47] K. Oberholzer, M. Menig, A. Kreft, A. Schneider, T. Junginger, A. Heintz, K.F. Kreitner, A.M. Hotker, T. Hansen, C. Duber, H. Schmidberger, Rectal cancer: mucinous carcinoma on magnetic resonance imaging indicates poor response to neoadjuvant chemoradiation, Int $\mathrm{J}$ Radiat Oncol Biol Phys, 82 (2012) 842-848.

[48] O. Poujade, P. Morice, R. Rouzier, P. Madelenat, F. Lecuru, J.M. Muray, P. Mathevet, S. Alran, R.J. Salmon, F. Reyal, Pathologic response rate after concomitant neo-adjuvant radiotherapy and chemotherapy for adenocarcinoma of the uterine cervix: a retrospective multicentric study, Int $\mathrm{J}$ Gynecol Cancer, 20 (2010) 815-820.

[49] M. Messager, J.H. Lefevre, V. Pichot-Delahaye, A. Souadka, G. Piessen, C. Mariette, The impact of perioperative chemotherapy on survival in patients with gastric signet ring cell adenocarcinoma: a multicenter comparative study, Ann Surg, 254 (2011) 684-693; discussion 693.

[50] B.V. Sinn, G. von Minckwitz, C. Denkert, H. Eidtmann, S. Darb-Esfahani, H. Tesch, R. Kronenwett, G. Hoffmann, A. Belau, C. Thommsen, H.J. Holzhausen, S.T. Grasshoff, K. Baumann, K. Mehta, M. Dietel, S. Loibl, Evaluation of Mucin-1 protein and mRNA expression as prognostic and predictive markers after neoadjuvant chemotherapy for breast cancer, Ann Oncol, 24 (2013) 23162324.

[51] S.P. Pitroda, N.N. Khodarev, M.A. Beckett, D.W. Kufe, R.R. Weichselbaum, MUC1-induced alterations in a lipid metabolic gene network predict response of human breast cancers to tamoxifen treatment, Proc Natl Acad Sci U S A, 106 (2009) 5837-5841.

[52] M. Takano, K. Fujii, T. Kita, Y. Kikuchi, K. Uchida, Amplicon profiling reveals cytoplasmic overexpression of MUC1 protein as an indicator of resistance to platinum-based chemotherapy in patients with ovarian cancer, Oncol Rep, 12 (2004) 1177-1182.

[53] D. Zhang, J. Gao, L. Zhu, Z. Hu, R. Hou, S. Liu, M. Tan, J. Liu, B. Lin, Chemoresistance Is Associated with MUC1 and Lewis y Antigen Expression in Ovarian Epithelial Cancers, Int J Mol Sci, 14 (2013) 11024-11033.

[54] P.G. Bhat, D.R. Flanagan, M.D. Donovan, Drug diffusion through cystic fibrotic mucus: steadystate permeation, rheologic properties, and glycoprotein morphology, J Pharm Sci, 85 (1996) 624-630.

[55] H.H. Sigurdsson, J. Kirch, C.M. Lehr, Mucus as a barrier to lipophilic drugs, Int J Pharm, 453 (2013) 56-64.

[56] L.R. Shaw, W.J. Irwin, T.J. Grattan, B.R. Conway, The influence of excipients on the diffusion of ibuprofen and paracetamol in gastric mucus, Int J Pharm, 290 (2005) 145-154.

[57] K. Khanvilkar, M.D. Donovan, D.R. Flanagan, Drug transfer through mucus, Adv Drug Deliv Rev, 48 (2001) 173-193.

[58] A.V. Kalra, R.B. Campbell, Mucin impedes cytotoxic effect of 5-FU against growth of human pancreatic cancer cells: overcoming cellular barriers for therapeutic gain, $\mathrm{Br} J$ Cancer, 97 (2007) 910 918.

[59] E. Leteurtre, V. Gouyer, D. Delacour, B. Hemon, A. Pons, C. Richet, J.P. Zanetta, G. Huet, Induction of a storage phenotype and abnormal intracellular localization of apical glycoproteins are two independent responses to GalNAcalpha-O-bn, J Histochem Cytochem, 51 (2003) 349-361.

[60] A.V. Kalra, R.B. Campbell, Mucin overexpression limits the effectiveness of 5-FU by reducing intracellular drug uptake and antineoplastic drug effects in pancreatic tumours, Eur $\mathrm{J}$ Cancer, 45 (2009) 164-173.

[61] G. Lafitte, K. Thuresson, O. Soderman, Diffusion of nutrients molecules and model drug carriers through mucin layer investigated by magnetic resonance imaging with chemical shift resolution, J Pharm Sci, 96 (2007) 258-263.

[62] J.A. Gubbels, M. Felder, S. Horibata, J.A. Belisle, A. Kapur, H. Holden, S. Petrie, M. Migneault, C. Rancourt, J.P. Connor, M.S. Patankar, MUC16 provides immune protection by inhibiting synapse formation between NK and ovarian tumor cells, Mol Cancer, 9 (2010) 11.

[63] M. Komatsu, L. Yee, K.L. Carraway, Overexpression of sialomucin complex, a rat homologue of MUC4, inhibits tumor killing by lymphokine-activated killer cells, Cancer Res, 59 (1999) 2229-2236.

[64] E. van de Wiel-van Kemenade, M.J. Ligtenberg, A.J. de Boer, F. Buijs, H.L. Vos, C.J. Melief, J. Hilkens, C.G. Figdor, Episialin (MUC1) inhibits cytotoxic lymphocyte-target cell interaction, J Immunol, 151 (1993) 767-776.

[65] S.A. Price-Schiavi, S. Jepson, P. Li, M. Arango, P.S. Rudland, L. Yee, K.L. Carraway, Rat Muc4 (sialomucin complex) reduces binding of anti-ErbB2 antibodies to tumor cell surfaces, a potential mechanism for herceptin resistance, Int J Cancer, 99 (2002) 783-791. 
[66] P. Nagy, E. Friedlander, M. Tanner, A.I. Kapanen, K.L. Carraway, J. Isola, T.M. Jovin, Decreased accessibility and lack of activation of ErbB2 in JIMT-1, a herceptin-resistant, MUC4-expressing breast cancer cell line, Cancer Res, 65 (2005) 473-482.

[67] J. Ren, N. Agata, D. Chen, Y. Li, W.H. Yu, L. Huang, D. Raina, W. Chen, S. Kharbanda, D. Kufe, Human MUC1 carcinoma-associated protein confers resistance to genotoxic anticancer agents, Cancer Cell, 5 (2004) 163-175.

[68] X. Wei, H. Xu, D. Kufe, Human MUC1 oncoprotein regulates p53-responsive gene transcription in the genotoxic stress response, Cancer Cell, 7 (2005) 167-178.

[69] R. Ahmad, M. Alam, H. Rajabi, D. Kufe, The MUC1-C oncoprotein binds to the BH3 domain of the pro-apoptotic BAX protein and blocks BAX function, J Biol Chem, 287 (2012) 20866-20875.

[70] D. Raina, R. Ahmad, S. Kumar, J. Ren, K. Yoshida, S. Kharbanda, D. Kufe, MUC1 oncoprotein blocks nuclear targeting of c-Abl in the apoptotic response to DNA damage, Embo J, 25 (2006) 37743783.

[71] D. Raina, R. Ahmad, D. Chen, S. Kumar, S. Kharbanda, D. Kufe, MUC1 oncoprotein suppresses activation of the ARF-MDM2-p53 pathway, Cancer Biol Ther, 7 (2008) 1959-1967.

[72] R. Ahmad, D. Raina, V. Trivedi, J. Ren, H. Rajabi, S. Kharbanda, D. Kufe, MUC1 oncoprotein activates the IkappaB kinase beta complex and constitutive NF-kappaB signalling, Nat Cell Biol, 9 (2007) 1419-1427.

[73] N. Agata, R. Ahmad, T. Kawano, D. Raina, S. Kharbanda, D. Kufe, MUC1 oncoprotein blocks death receptor-mediated apoptosis by inhibiting recruitment of caspase-8, Cancer Res, 68 (2008) 6136-6144.

[74] A. Bouillez, V. Gnemmi, K. Gaudelot, B. Hemon, B. Ringot, N. Pottier, F. Glowacki, C. Butruille, C. Cauffiez, M. Hamdane, N. Sergeant, I. Van Seuningen, X. Leroy, S. Aubert, M. Perrais, MUC1-C nuclear localization drives invasiveness of renal cancer cells through a sheddase/gamma secretase dependent pathway, Oncotarget, 5 (2014) 754-763.

[75] A.T. Lau, Y. Wang, J.F. Chiu, Reactive oxygen species: current knowledge and applications in cancer research and therapeutic, J Cell Biochem, 104 (2008) 657-667.

[76] P. Storz, Reactive oxygen species in tumor progression, Front Biosci, 10 (2005) 1881-1896.

[77] L. Yin, Y. Li, J. Ren, H. Kuwahara, D. Kufe, Human MUC1 carcinoma antigen regulates intracellular oxidant levels and the apoptotic response to oxidative stress, J Biol Chem, 278 (2003) 35458-35464.

[78] L. Yin, L. Huang, D. Kufe, MUC1 oncoprotein activates the FOXO3a transcription factor in a survival response to oxidative stress, J Biol Chem, 279 (2004) 45721-45727.

[79] J.P. Fruehauf, F.L. Meyskens, Jr., Reactive oxygen species: a breath of life or death?, Clin Cancer Res, 13 (2007) 789-794.

[80] S. Aubert, V. Fauquette, B. Hemon, R. Lepoivre, N. Briez, D. Bernard, I. Van Seuningen, X. Leroy, $M$. Perrais, MUC1, a new hypoxia inducible factor target gene, is an actor in clear renal cell carcinoma tumor progression, Cancer Res, 69 (2009) 5707-5715.

[81] P. Chaturvedi, A.P. Singh, N. Moniaux, S. Senapati, S. Chakraborty, J.L. Meza, S.K. Batra, MUC4 mucin potentiates pancreatic tumor cell proliferation, survival, and invasive properties and interferes with its interaction to extracellular matrix proteins, Mol Cancer Res, 5 (2007) 309-320.

[82] N. Moniaux, P. Chaturvedi, G.C. Varshney, J.L. Meza, J.F. Rodriguez-Sierra, J.P. Aubert, S.K. Batra, Human MUC4 mucin induces ultra-structural changes and tumorigenicity in pancreatic cancer cells, Br J Cancer, 97 (2007) 345-357.

[83] M.P. Torres, M.P. Ponnusamy, S. Chakraborty, L.M. Smith, S. Das, H.A. Arafat, S.K. Batra, Effects of thymoquinone in the expression of mucin 4 in pancreatic cancer cells: implications for the development of novel cancer therapies, Mol Cancer Ther, 9 (2010) 1419-1431.

[84] N. Jonckheere, N. Skrypek, J. Merlin, A.F. Dessein, P. Dumont, E. Leteurtre, A. Harris, J.L. Desseyn, C. Susini, F. Frenois, I. Van Seuningen, The Mucin MUC4 and Its Membrane Partner ErbB2 Regulate Biological Properties of Human CAPAN-2 Pancreatic Cancer Cells via Different Signalling Pathways, PLoS One, 7 (2012) e32232.

[85] M. Komatsu, S. Jepson, M.E. Arango, C.A. Carothers Carraway, K.L. Carraway, Muc4/sialomucin complex, an intramembrane modulator of ErbB2/HER2/Neu, potentiates primary tumor growth and suppresses apoptosis in a xenotransplanted tumor, Oncogene, 20 (2001) 461-470.

[86] S. Jepson, M. Komatsu, B. Haq, M.E. Arango, D. Huang, C.A. Carraway, K.L. Carraway, Muc4/sialomucin complex, the intramembrane ErbB2 ligand, induces specific phosphorylation of ErbB2 and enhances expression of p27(kip), but does not activate mitogen-activated kinase or protein kinaseB/Akt pathways, Oncogene, 21 (2002) 7524-7532. 
[87] H.C. Workman, C. Sweeney, K.L. Carraway, 3rd, The membrane mucin Muc4 inhibits apoptosis induced by multiple insults via ErbB2-dependent and ErbB2-independent mechanisms, Cancer Res, 69 (2009) 2845-2852.

[88] A. El-Khattouti, D. Selimovic, Y. Haikel, M. Megahed, C.R. Gomez, M. Hassan, Identification and analysis of CD133(+) melanoma stem-like cells conferring resistance to taxol: An insight into the mechanisms of their resistance and response, Cancer Lett, 343 (2014) 123-133.

[89] J. Li, X.Y. Zhong, Z.Y. Li, J.F. Cai, L. Zou, J.M. Li, T. Yang, W. Liu, CD133 expression in osteosarcoma and derivation of CD133(+) cells, Mol Med Rep, 7 (2013) 577-584.

[90] S. Nath, K. Daneshvar, L.D. Roy, P. Grover, A. Kidiyoor, L. Mosley, M. Sahraei, P. Mukherjee, MUC1 induces drug resistance in pancreatic cancer cells via upregulation of multidrug resistance genes, Oncogenesis, 2 (2013) e51.

[91] F.J. Sharom, ABC multidrug transporters: structure, function and role in chemoresistance, Pharmacogenomics, 9 (2008) 105-127.

[92] M. Greaves, C.C. Maley, Clonal evolution in cancer, Nature, 481 (2012) 306-313.

[93] P.B. Gupta, T.T. Onder, G. Jiang, K. Tao, C. Kuperwasser, R.A. Weinberg, E.S. Lander, Identification of selective inhibitors of cancer stem cells by high-throughput screening, Cell, 138 (2009) 645-659.

[94] M. Alam, R. Ahmad, H. Rajabi, A. Kharbanda, D. Kufe, MUC1-C oncoprotein activates ERK-$>\mathrm{C} / \mathrm{EBPbeta}$ signaling and induction of aldehyde dehydrogenase $1 \mathrm{~A} 1$ in breast cancer cells, J Biol Chem, 288 (2013) 30892-30903.

[95] D. Stroopinsky, J. Rosenblatt, K. Ito, H. Mills, L. Yin, H. Rajabi, B. Vasir, T. Kufe, K. Luptakova, J. Arnason, C. Nardella, J.D. Levine, R.M. Joyce, I. Galinsky, Y. Reiter, R.M. Stone, P.P. Pandolfi, D. Kufe, D. Avigan, MUC1 is a potential target for the treatment of acute myeloid leukemia stem cells, Cancer Res, 73 (2013) 5569-5579.

[96] M.P. Ponnusamy, P. Seshacharyulu, A. Vaz, P. Dey, S.K. Batra, MUC4 stabilizes HER2 expression and maintains the cancer stem cell population in ovarian cancer cells, J Ovarian Res, 4 (2011) 7.

[97] A. Jimeno, G. Feldmann, A. Suarez-Gauthier, Z. Rasheed, A. Solomon, G.M. Zou, B. RubioViqueira, E. Garcia-Garcia, F. Lopez-Rios, W. Matsui, A. Maitra, M. Hidalgo, A direct pancreatic cancer xenograft model as a platform for cancer stem cell therapeutic development, Mol Cancer Ther, 8 (2009) 310-314.

[98] J. Zhou, C.Y. Wang, T. Liu, B. Wu, F. Zhou, J.X. Xiong, H.S. Wu, J. Tao, G. Zhao, M. Yang, S.M. Gou, Persistence of side population cells with high drug efflux capacity in pancreatic cancer, World $\mathrm{J}$ Gastroenterol, 14 (2008) 925-930.

[99] J.P. Thiery, H. Acloque, R.Y. Huang, M.A. Nieto, Epithelial-mesenchymal transitions in development and disease, Cell, 139 (2009) 871-890.

[100] J.P. Thiery, J.P. Sleeman, Complex networks orchestrate epithelial-mesenchymal transitions, Nat Rev Mol Cell Biol, 7 (2006) 131-142.

[101] S. Lamouille, D. Subramanyam, R. Blelloch, R. Derynck, Regulation of epithelial-mesenchymal and mesenchymal-epithelial transitions by microRNAs, Curr Opin Cell Biol, 25 (2013) 200-207.

[102] M.K. Wendt, M. Tian, W.P. Schiemann, Deconstructing the mechanisms and consequences of TGF-beta-induced EMT during cancer progression, Cell Tissue Res, 347 (2012) 85-101.

[103] N. Ahmed, K. Abubaker, J. Findlay, M. Quinn, Epithelial mesenchymal transition and cancer stem cell-like phenotypes facilitate chemoresistance in recurrent ovarian cancer, Curr Cancer Drug Targets, 10 (2010) 268-278.

[104] S. Lim, A. Becker, A. Zimmer, J. Lu, R. Buettner, J. Kirfel, SNAl1-mediated epithelialmesenchymal transition confers chemoresistance and cellular plasticity by regulating genes involved in cell death and stem cell maintenance, PLoS One, 8 (2013) e66558.

[105] A. Voulgari, A. Pintzas, Epithelial-mesenchymal transition in cancer metastasis: mechanisms, markers and strategies to overcome drug resistance in the clinic, Biochim Biophys Acta, 1796 (2009) 75-90.

[106] S. Yamada, B.C. Fuchs, T. Fujii, Y. Shimoyama, H. Sugimoto, S. Nomoto, S. Takeda, K.K. Tanabe, Y. Kodera, A. Nakao, Epithelial-to-mesenchymal transition predicts prognosis of pancreatic cancer, Surgery, 154 (2013) 946-954.

[107] M. Comamala, M. Pinard, C. Theriault, I. Matte, A. Albert, M. Boivin, J. Beaudin, A. Piche, C. Rancourt, Downregulation of cell surface CA125/MUC16 induces epithelial-to-mesenchymal transition and restores EGFR signalling in NIH:OVCAR3 ovarian carcinoma cells, Br J Cancer, 104 (2011) 989999. 
[108] G. Horn, A. Gaziel, D.H. Wreschner, N.I. Smorodinsky, M. Ehrlich, ERK and PI3K regulate different aspects of the epithelial to mesenchymal transition of mammary tumor cells induced by truncated MUC1, Exp Cell Res, 315 (2009) 1490-1504.

[109] L.D. Roy, M. Sahraei, D.B. Subramani, D. Besmer, S. Nath, T.L. Tinder, E. Bajaj, K. Shanmugam, Y.Y. Lee, S.I. Hwang, S.J. Gendler, P. Mukherjee, MUC1 enhances invasiveness of pancreatic cancer cells by inducing epithelial to mesenchymal transition, Oncogene, 30 (2011) 14491459.

[110] M.P. Ponnusamy, I. Lakshmanan, M. Jain, S. Das, S. Chakraborty, P. Dey, S.K. Batra, MUC4 mucin-induced epithelial to mesenchymal transition: a novel mechanism for metastasis of human ovarian cancer cells, Oncogene, 29 (2010) 5741-5754.

[111] H. Rajabi, M. Alam, H. Takahashi, A. Kharbanda, M. Guha, R. Ahmad, D. Kufe, MUC1-C oncoprotein activates the ZEB1/miR-200c regulatory loop and epithelial-mesenchymal transition, Oncogene, 33 (2014) 1680-1689.

[112] V. Gnemmi, A. Bouillez, K. Gaudelot, B. Hemon, B. Ringot, N. Pottier, F. Glowacki, A. Villers, D. Vindrieux, C. Cauffiez, I.V. Seuningen, D. Bernard, X. Leroy, S. Aubert, M. Perrais, MUC1 drives epithelial-mesenchymal transition in renal carcinoma through Wnt/beta-catenin pathway and interaction with SNAIL promoter, Cancer Lett, 346 (2014) 225-236.

[113] L. Gao, J. Liu, B. Zhang, H. Zhang, D. Wang, T. Zhang, Y. Liu, C. Wang, Functional MUC4 suppress epithelial-mesenchymal transition in lung adenocarcinoma metastasis, Tumour Biol, 35 (2014) 1335-1341.

[114] N. Jonckheere, I. Van Seuningen, Comment on: Functional MUC4 suppress epithelialmesenchymal transition in lung adenocarcinoma metastasis. Gao L, Liu J, Zhang B, Zhang H, Wang D, Zhang T, Liu Y, Wang C. Tumour Biol. 2013, in press, Tumour Biol, 35 (2014) 3941-3942.

[115] T. Fujii, K. Shimada, S. Anai, K. Fujimoto, N. Konishi, ALKBH2, a novel AlkB homologue, contributes to human bladder cancer progression by regulating MUC1 expression, Cancer Sci, 104 (2013) 321-327.

[116] J.W. Lee, F. Aminkeng, A.P. Bhavsar, K. Shaw, B.C. Carleton, M.R. Hayden, C.J. Ross, The Emerging Era of Pharmacogenomics: Current Successes, Future Potential, and Challenges, Clin Genet, in press (2014).

[117] C. Ono, H. Kikkawa, A. Suzuki, M. Suzuki, Y. Yamamoto, K. Ichikawa, M. Fukae, I. leiri, Clinical impact of genetic variants of drug transporters in different ethnic groups within and across regions, Pharmacogenomics, 14 (2013) 1745-1764.

[118] K. Sai, Y. Saito, Ethnic differences in the metabolism, toxicology and efficacy of three anticancer drugs, Expert Opin Drug Metab Toxicol, 7 (2011) 967-988.

[119] C.Y. Chang, H.W. Chang, C.M. Chen, C.Y. Lin, C.P. Chen, C.H. Lai, W.Y. Lin, H.P. Liu, J.J. Sheu, F.J. Tsai, MUC4 gene polymorphisms associate with endometriosis development and endometriosis-related infertility, BMC Med, 9 (2011) 19.

[120] N. Saeki, A. Saito, I.J. Choi, K. Matsuo, S. Ohnami, H. Totsuka, S. Chiku, A. Kuchiba, Y.S. Lee, K.A. Yoon, M.C. Kook, S.R. Park, Y.W. Kim, H. Tanaka, K. Tajima, H. Hirose, F. Tanioka, Y. Matsuno, H. Sugimura, S. Kato, T. Nakamura, T. Nishina, W. Yasui, K. Aoyagi, H. Sasaki, K. Yanagihara, H. Katai, T. Shimoda, T. Yoshida, Y. Nakamura, S. Hirohashi, H. Sakamoto, A functional single nucleotide polymorphism in mucin 1, at chromosome 1q22, determines susceptibility to diffuse-type gastric cancer, Gastroenterology, 140 (2011) 892-902.

[121] Y. Horimasu, N. Hattori, N. Ishikawa, S. Kawase, S. Tanaka, K. Yoshioka, A. Yokoyama, N. Kohno, F. Bonella, J. Guzman, S. Ohshimo, U. Costabel, Different MUC1 gene polymorphisms in German and Japanese ethnicities affect serum KL-6 levels, Respir Med, 106 (2012) 1756-1764.

[122] J. Fowler, L. Vinall, D. Swallow, Polymorphism of the human muc genes, Front Biosci, 6 (2001) D1207-1215.

[123] F. Carvalho, R. Seruca, L. David, A. Amorim, M. Seixas, E. Bennett, H. Clausen, M. SobrinhoSimoes, MUC1 gene polymorphism and gastric cancer--an epidemiological study, Glycoconj J, 14 (1997) 107-111.

[124] J.R. Davies, C. Wickstrom, D.J. Thornton, Gel-forming and cell-associated mucins: preparation for structural and functional studies, Methods Mol Biol, 842 (2012) 27-47.

[125] L. Yin, R. Ahmad, M. Kosugi, T. Kufe, B. Vasir, D. Avigan, S. Kharbanda, D. Kufe, Survival of human multiple myeloma cells is dependent on MUC1 C-terminal transmembrane subunit oncoprotein function, Mol Pharmacol, 78 (2010) 166-174.

[126] A. Kharbanda, H. Rajabi, C. Jin, D. Raina, D. Kufe, Oncogenic MUC1-C Promotes Tamoxifen Resistance in Human Breast Cancer, Mol Cancer Res, 11 (2013) 714-723. 
[127] D. Raina, Y. Uchida, A. Kharbanda, H. Rajabi, G. Panchamoorthy, C. Jin, S. Kharbanda, M. Scaltriti, J. Baselga, D. Kufe, Targeting the MUC1-C oncoprotein downregulates HER2 activation and abrogates trastuzumab resistance in breast cancer cells, Oncogene, in press (2013).

[128] Y. Uchida, D. Raina, S. Kharbanda, D. Kufe, Inhibition of the MUC1-C oncoprotein is synergistic with cytotoxic agents in the treatment of breast cancer cells, Cancer Biol Ther, 14 (2013) 127-134.

[129] D. Raina, M. Kosugi, R. Ahmad, G. Panchamoorthy, H. Rajabi, M. Alam, T. Shimamura, G.I. Shapiro, J. Supko, S. Kharbanda, D. Kufe, Dependence on the MUC1-C oncoprotein in non-small cell lung cancer cells, Mol Cancer Ther, 10 (2011) 806-816.

[130] C.K. Tang, V. Apostolopoulos, Strategies used for MUC1 immunotherapy: preclinical studies, Expert Rev Vaccines, 7 (2008) 951-962.

[131] C.K. Tang, M. Katsara, V. Apostolopoulos, Strategies used for MUC1 immunotherapy: human clinical studies, Expert Rev Vaccines, 7 (2008) 963-975.

[132] V. Lakshminarayanan, P. Thompson, M.A. Wolfert, T. Buskas, J.M. Bradley, L.B. Pathangey, C.S. Madsen, P.A. Cohen, S.J. Gendler, G.J. Boons, Immune recognition of tumor-associated mucin MUC1 is achieved by a fully synthetic aberrantly glycosylated MUC 1 tripartite vaccine, Proc Natl Acad Sci U S A, 109 (2011) 261-266.

[133] R.E. Beatson, J. Taylor-Papadimitriou, J.M. Burchell, MUC1 immunotherapy, Immunotherapy, 2 (2010) 305-327.

[134] N. Liu, C. Zhou, J. Zhao, Y. Chen, Reversal of paclitaxel resistance in epithelial ovarian carcinoma cells by a MUC1 aptamer-let-7i chimera, Cancer Invest, 30 (2012) 577-582.

[135] F. Dai, Y. Zhang, X. Zhu, N. Shan, Y. Chen, The anti-chemoresistant effect and mechanism of MUC1 aptamer-miR-29b chimera in ovarian cancer, Gynecol Oncol, 131 (2013) 451-459.

[136] M.J. Duffy, Tumor markers in clinical practice: a review focusing on common solid cancers, Med Princ Pract, 22 (2013) 4-11.

[137] L.F. de Campos-Lobato, D.W. Dietz, L. Stocchi, J.D. Vogel, I.C. Lavery, J.R. Goldblum, M. Skacel, R.J. Pelley, M.F. Kalady, Clinical implications of acellular mucin pools in resected rectal cancer with pathological complete response to neoadjuvant chemoradiation, Colorectal Dis, 14 (2012) 62-67.

[138] K.D. Smith, D. Tan, P. Das, G.J. Chang, K. Kattepogu, B.W. Feig, J.M. Skibber, M.A. RodriguezBigas, Clinical significance of acellular mucin in rectal adenocarcinoma patients with a pathologic complete response to preoperative chemoradiation, Ann Surg, 251 (2010) 261-264.

[139] J. Shia, M. McManus, J.G. Guillem, T. Leibold, Q. Zhou, L.H. Tang, E.R. Riedel, M.R. Weiser, P.B. Paty, L.K. Temple, G. Nash, K. Kolosov, B.D. Minsky, W.D. Wong, D.S. Klimstra, Significance of acellular mucin pools in rectal carcinoma after neoadjuvant chemoradiotherapy, Am J Surg Pathol, 35 (2011) 127-134.

[140] R.A. Budiu, G. Mantia-Smaldone, E. Elishaev, T. Chu, J. Thaller, K. McCabe, D. Lenzner, R.P. Edwards, A.M. Vlad, Soluble MUC1 and serum MUC1-specific antibodies are potential prognostic biomarkers for platinum-resistant ovarian cancer, Cancer Immunol Immunother, 60 (2011) 975-984.

[141] S. Aubert, I. Van Seuningen, X. Leroy, Mucins in the uro-genital tract. Potential for therapeutic approaches using mucins, in: I. Van Seuningen (Ed.) The Epithelial Mucins: Structure/Function. Roles in Cancer and Inflammatory Diseases, Research Signpost, Kerala, India, 2008, pp. 249-272.

[142] D. Di Gioia, V. Heinemann, D. Nagel, M. Untch, S. Kahlert, I. Bauerfeind, T. Koehnke, P. Stieber, Kinetics of CEA and CA15-3 correlate with treatment response in patients undergoing chemotherapy for metastatic breast cancer (MBC), Tumour Biol, 32 (2011) 777-785.

[143] J.P. Cheng, Y. Yan, X.Y. Wang, Y.L. Lu, Y.H. Yuan, J. Jia, J. Ren, MUC1-positive circulating tumor cells and MUC1 protein predict chemotherapeutic efficacy in the treatment of metastatic breast cancer, Chin J Cancer, 30 (2011) 54-61. 


\section{Figure legends}

Figure 1: Mucins and chemoresistance in epithelial cells. (A) Secreted and membranebound mucins form a physical barrier blocking the accessibility of the cell to therapeutic drugs. Mucin overexpression is associated with (B) apoptosis resistance, (C) drug exclusion or reduction of drug intake, (D) cell stemness and (E) epithelial-mesenchymal transition. Cancer stem cells (CSC) belong to the small subset of cells (side population) commonly expressing CSC markers such as CD133 visualized here by flow cytometry. EMT is associated by the loss of cell polarity, decreased expression of epithelial markers and increased expression of mesenchymal markers (e.g. vimentin).

Figure 2: MUC1 overexpression and associated cellular mechanisms of chemoresistance in epithelial cancer cells.

Figure 3: MUC4 overexpression and associated cellular mechanisms of chemoresistance in epithelial cancer cells. 
Table 1: Mucins and drug chemoresistance in epithelial cancer cells

\begin{tabular}{|c|c|c|c|}
\hline Mucin & Drug & Tumor type & Refs \\
\hline \multicolumn{4}{|c|}{ Membrane-bound mucins } \\
\hline \multirow[t]{7}{*}{ MUC1 } & 5-FU/Methotrexate & CRC & {$[34,35]$} \\
\hline & $5-\mathrm{FU}$ & PDAC & {$[58,60]$} \\
\hline & Cisplatin & Ovarian & [52] \\
\hline & Cisplatin & CRC & [67] \\
\hline & $\begin{array}{l}\text { Taxane/Platinum } \\
\text { compound }\end{array}$ & Ovarian & [53] \\
\hline & $\begin{array}{l}\text { Trastuzumab/ } \\
\text { Paclitaxel/Doxorubicin/ } \\
\text { Cyclophosphamide }\end{array}$ & Breast Cancer & [36] \\
\hline & Gemcitabine/Etoposide & PDAC & [90] \\
\hline MUC3 & Methotrexate & CRC & [34] \\
\hline \multirow[t]{7}{*}{ MUC4 } & $5-\mathrm{FU}$ & CRC & [34] \\
\hline & Lapatinib/Trastuzumab & Breast Cancer & [39] \\
\hline & Trastuzumab & $\begin{array}{l}\text { Melanoma/Breast } \\
\text { Cancer }\end{array}$ & [65] \\
\hline & Cytarabine/Aracytin & PDAC & [42] \\
\hline & $\begin{array}{l}\text { Paclitaxel/Doxorubicin/ } \\
\text { Vinblastine/Rhodamine- } \\
\text { 123/2-deoxyglucose }\end{array}$ & Melanoma & [44] \\
\hline & Bortezomib & PDAC & [43] \\
\hline & Gemcitabine & PDAC & [40-42] \\
\hline \multicolumn{4}{|c|}{ Secreted mucins } \\
\hline MUC5AC & 5-FU/Methotrexate & CRC & {$[34,35]$} \\
\hline MUC5B & 5-FU/Methotrexate & CRC & {$[34,35]$} \\
\hline MUC2 & $5-\mathrm{FU}$ & CRC & [34] \\
\hline
\end{tabular}


Figure 1

A

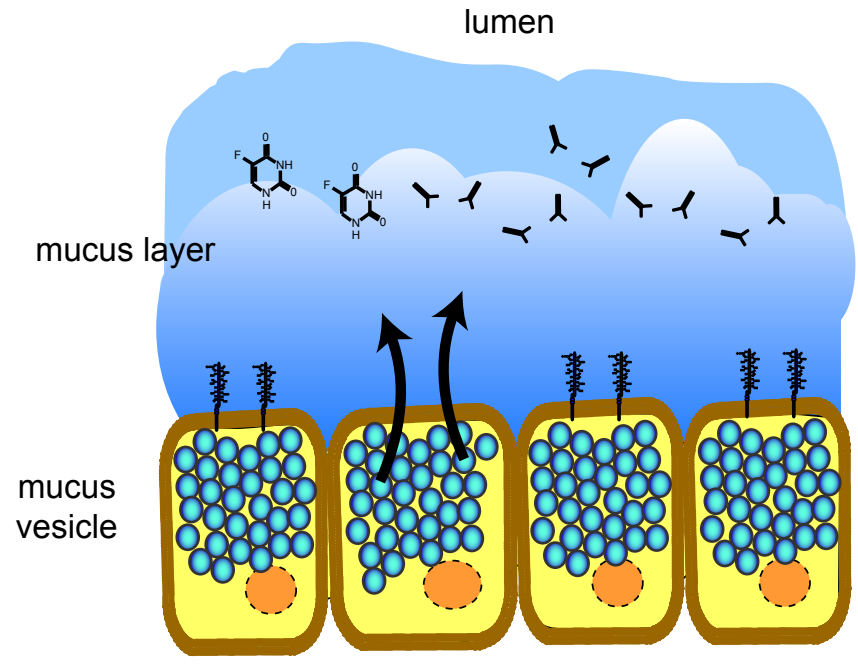

secreted mucins

B

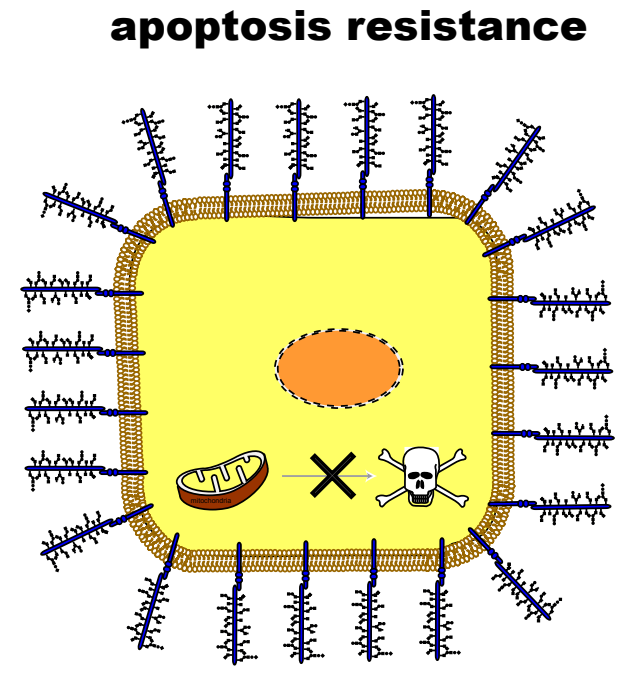

\section{cell stemness}

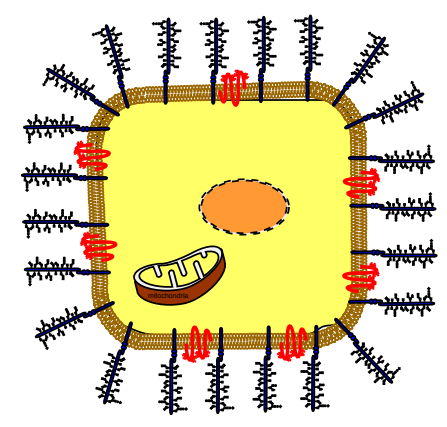

Stem cell markers

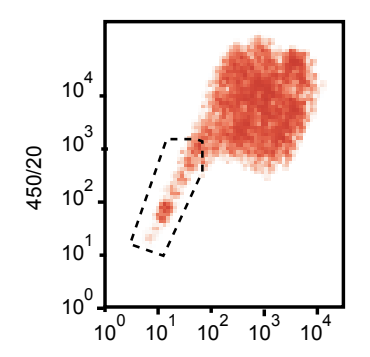
physical barrier $+1{ }^{\lambda}+1^{\text {targeted therapy (antibody) }}$ $\gamma^{l}+1 \gamma^{l}$

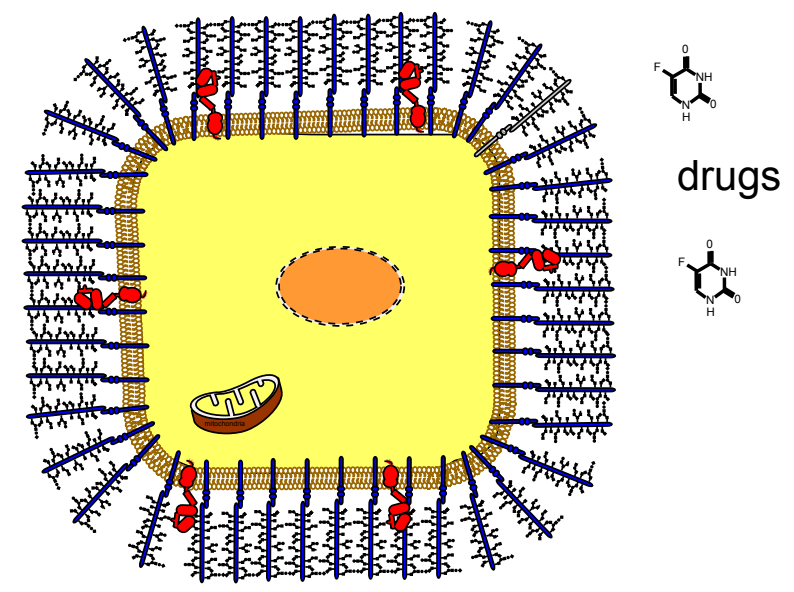

membrane bound mucins

C drug exclusion decreased entrance of the drug

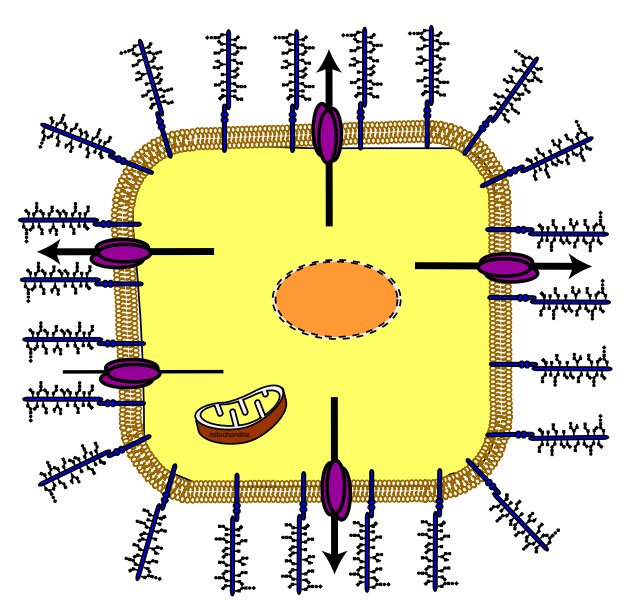

E

\section{epithelium mesenchymal transition (EMT)}

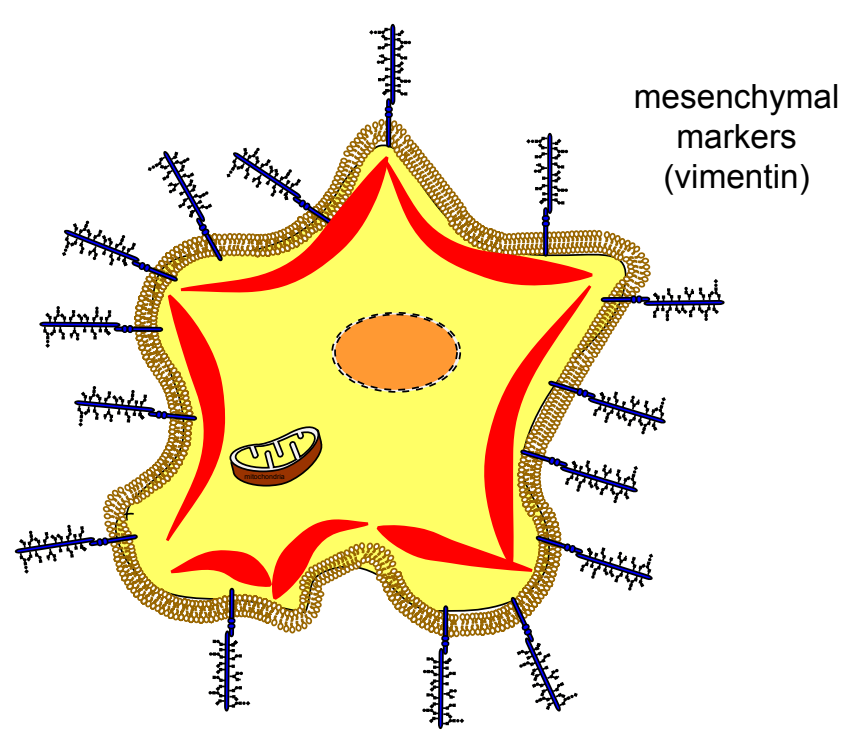




\section{Figure 2}

Figure 2

\section{steric hindrance blockage}

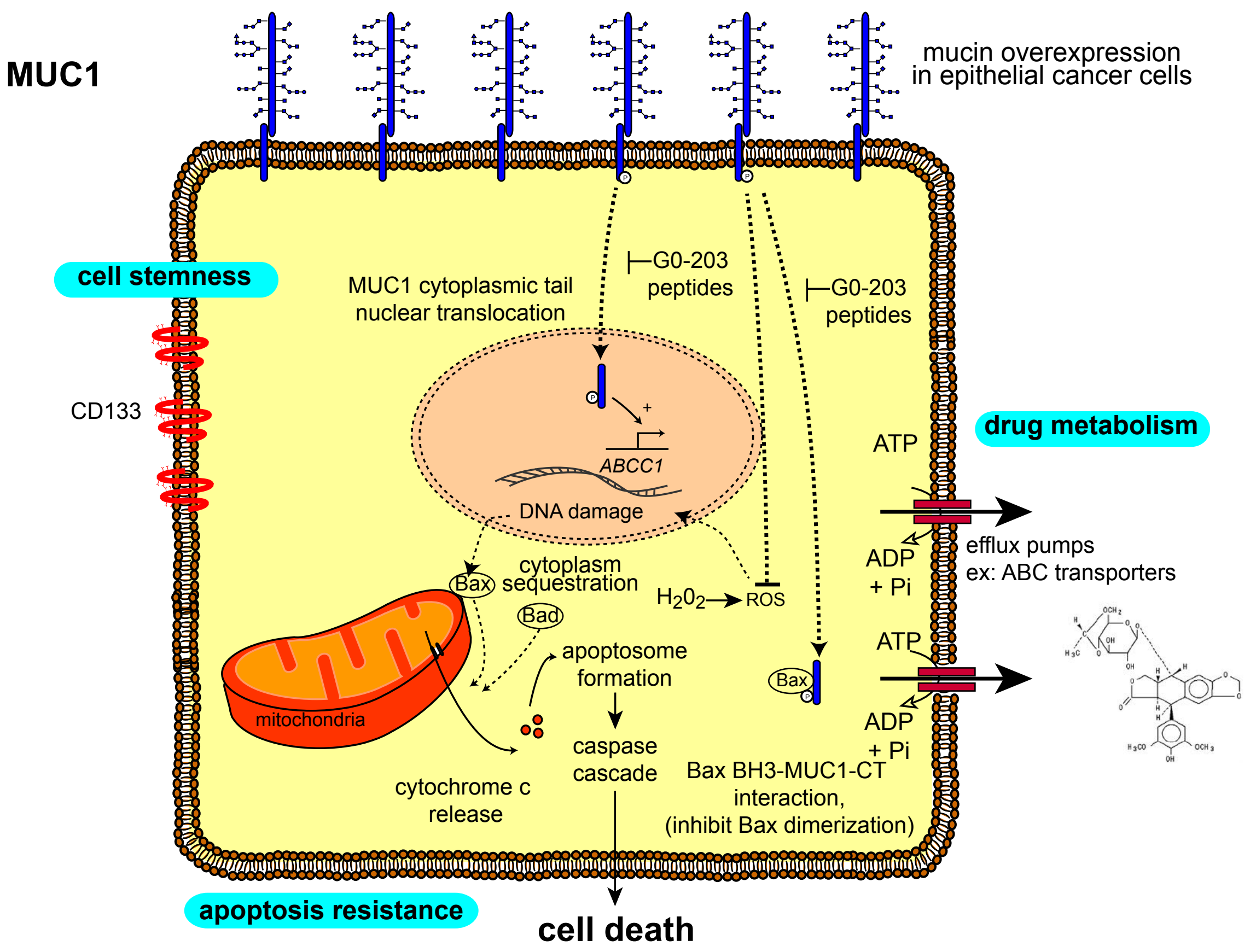




\section{Figure 3}

Figure 3

steric hindrance blockage

- targeted therapy ex: trastuzumab

$+1$

MUC4

cell stemness
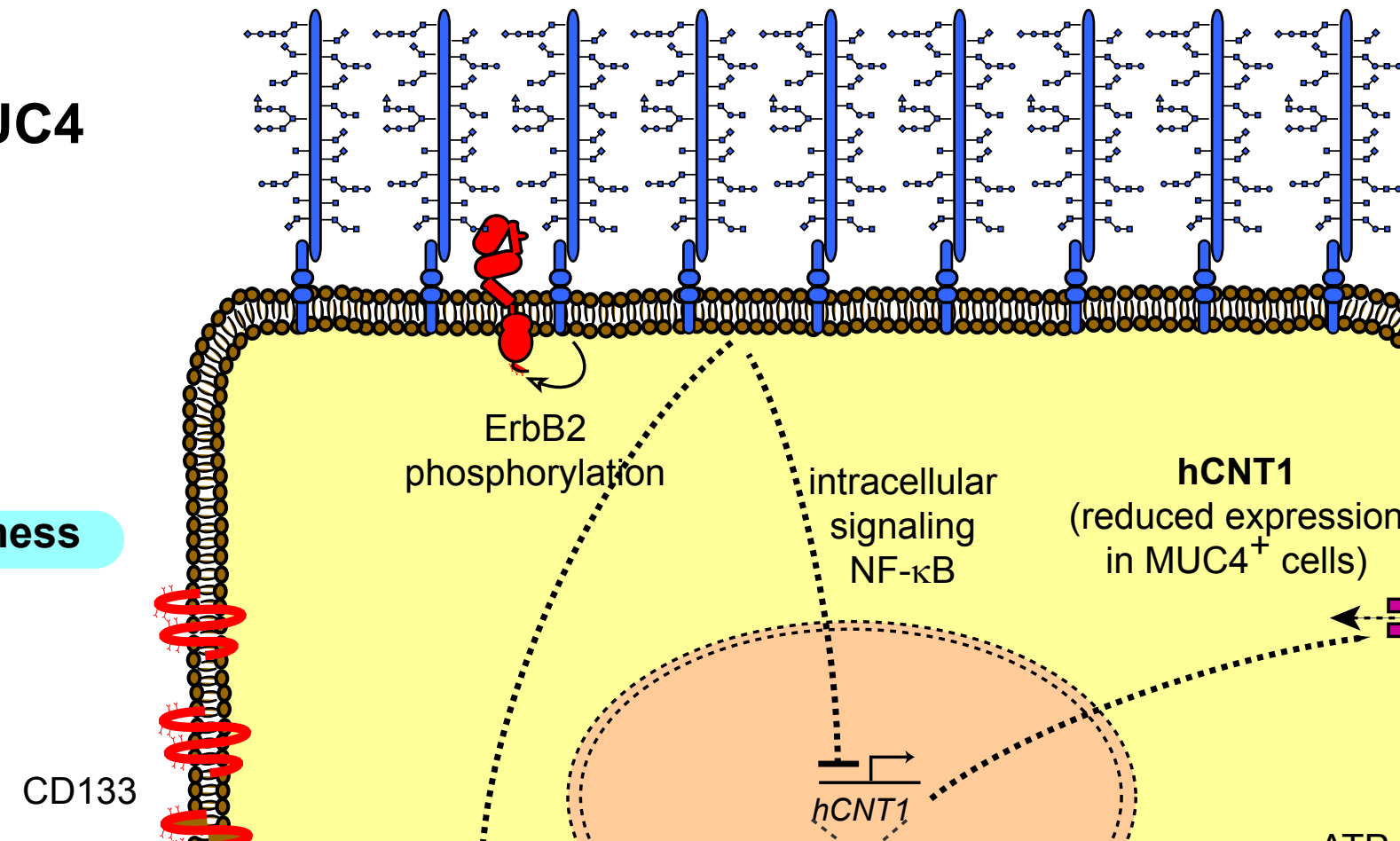
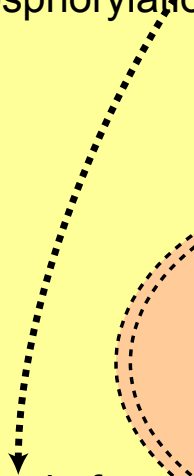

intracellular

signaling

hCNT1

(reduced expression

in $\mathrm{MUC}^{+}$cells)

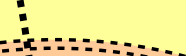

increase level of

ex:

赵

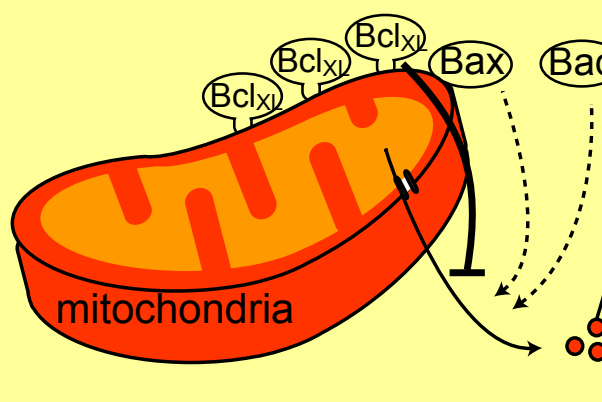

cytochrome c release

cytoplasm
sequestration
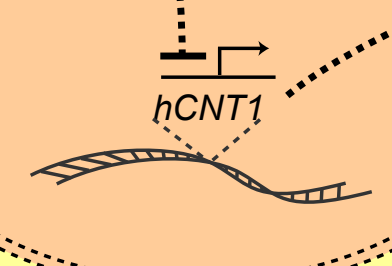

apoptosome

formation

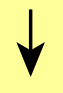

caspase

cascade nucleotide analog

ex: gemcitabine

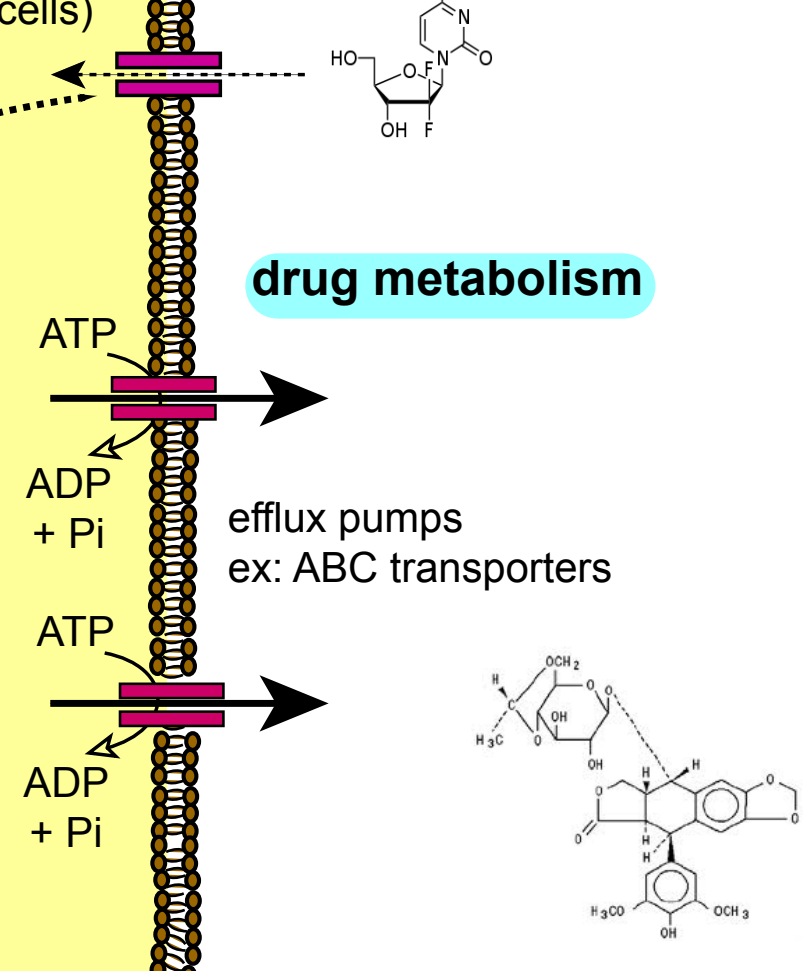

